\title{
VIBRATIONAL SCALING FACTORS FOR Rh(I) CARBONYL COMPOUNDS IN HOMOGENEOUS CATALYSIS ${ }^{\bullet}$
}

\author{
Emilija Kohls", Matthias Stein \\ Max Planck Institute for Dynamics of Complex Technical Systems, \\ Molecular Simulations and Design Group, Sandtorstr. 1, 39106 Magdeburg, Germany \\ "e-mail: kohls@mpi-magdeburg.mpg.de
}

\begin{abstract}
Metal carbonyl complexes are an important family of catalysts in homogeneous industrial processes. Their characteristic vibrational frequencies allow in situ tracking of catalytic progress. Structural assignment of intermediates is often hampered by the lack of appropriate reference compounds. The calculation of carbonyl vibrational frequencies from first principles provides an alternative tool to identify such reactive intermediates. Scaling factors for computed vibrational carbonyl stretching frequencies were derived from a training set of $45 \mathrm{Rh}$-carbonyl complexes using the BP86 and B3LYP functionals. The systematic scaling of the computed $\mathrm{C}=\mathrm{O}$ frequencies yields accurate calculation and assignment of the experimentally obtained $v(\mathrm{CO})$ values. The vibrational scaling factors can be used to identify reaction intermediates of the industrially relevant $\mathrm{Rh}$-catalyzed hydroformylation reaction. The absolute error between calculated and experimental spectra was significantly reduced and the experimental spectra were assigned successfully.
\end{abstract}

Key words: infrared spectroscopy; vibrational scaling factors; rhodium-carbonyl complexes; hydroformylation; DFT

\section{INTRODUCTION}

Hydroformylation of alkenes (also known as "oxo process") is one of the most important homogeneously catalysed industrial processes with a yearly production of more than 10 million metric tons of oxo chemicals [1]. The produced aldehydes from olefins and syngas $\left(\mathrm{CO} / \mathrm{H}_{2}\right)$ are used as perfumes, surfactants, plasticizers and solvents. Owing to the milder process conditions, rhodium(I) carbonyl complexes are the predominant catalysts of choice [2]. For the purpose of achieving higher n/iso selectivity, rhodium carbonyl complexes are modified with bulky phosphine or phosphite ligands. Aryl diphosphite compounds are attractive modifying ligands offering high catalytic activity and selectivity on one hand, and ease of preparation in comparison to phosphines on the other [3]. Also being generally less sensitive to sulfur compounds and oxidizing agents, bulky aryl diphosphites are the first choice for selective production of large quantities of $n$-aldehydes. Phosphite ligands, such as BiPhePhos, provide $98-99 \% n$-selectivity [4]. The ligand $\mathrm{BiPhePhos}$ and $\mathrm{Rh}(\mathrm{I}) \mathrm{BiPhePhos}$ precatalyst with two carbonyl and one hydride ligand are shown in Figure 1. In addition to hydroformylation purposes, rhodium carbonyl complexes are also important catalysts in a number of other large-scale homogeneously catalysed industrial processes, e.g. the production of acetic acid (the Monsanto process) [5].

Understanding the mechanism of the complex catalytic reaction networks and establishing structure-selectivity/reactivity relationships is incredibly valuable for the further development of catalysts and processes, as well as for tailoring new catalysts. Infrared (IR) spectroscopy plays a very important role in metal carbonyl chemistry for gaining mechanistic insight and the bands due to CO absorption, occurring around $2000 \mathrm{~cm}^{-1}$, are especially informative. Operando IR spectroscopy 
is an advancing in situ methodology to monitor formation and disappearance of intermediate species in real time, under working conditions at elevated pressures and temperatures using timeresolved spectra [6].

For (carbonyl containing) Rh catalysts, the $\mathrm{C}=\mathrm{O}$ stretching frequencies are of crucial im- portance to deduce structural information of intermediate complexes during the reaction. With $\mathrm{CO}$ being a strong $\pi$ acceptor ligand, the strength of the $\mathrm{Rh}-\mathrm{CO}$ bond and consequently frequency of vibration of the $\mathrm{C}-\mathrm{O}$ bond will depend on the electron density at the rhodium atom.
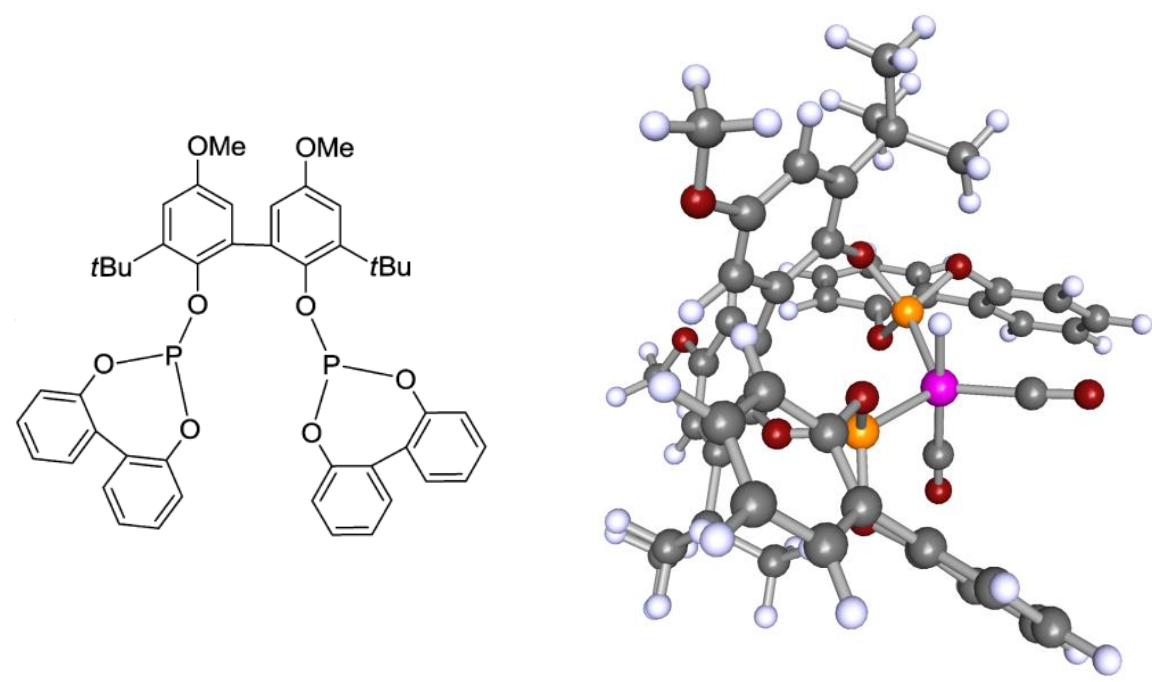

Figure 1. Structure of BiPhePhos ligand (left). DFT(BP86/def2-TZVP) optimized $\mathrm{HRh}(\mathrm{BiPhePhos})(\mathrm{CO})_{2}$ hydroformylation pre-catalyst (right).

$\mathrm{CO}$ stretching vibrations are very sensitive to their chemical environment, give rise to sharp and intense bands well separated from other vibrations in the spectrum. All of this explains why IR is the most important technique for rationalizing the structure of $\mathrm{CO}$ complexes. Assignment of the resulting spectra, however, is almost never unambiguous. $A b$ initio calculated frequencies have been recognized as an inevitable tool in structural assignment and interpretation of complex vibrational spectra. For larger molecules and transition metal complexes, density functional theory (DFT) is the method of choice due to its computational efficiency $[7,8]$. However, due to intrinsic biases of the theoretical models, the computed frequencies are shifted with respect to the experimental ones. This has its origins in approximating vibrational movements of a molecule to be harmonic. Other sources of error are the use of a finite basis set and the neglect of electron correlation. Further source of error is that the computed frequencies stem from isolated molecules (gas phase) whereas the measured spectra are usually done on liquid or solid samples where perturbations from solvent, counter ions or matrix environment are present. Thus the computed harmonic vibrational frequencies are typically larger than the experimentally observed fundamentals
[9]. The discrepancies between computed and measured vibrational frequencies tend to be systematic. This makes it possible to correct ab initio frequencies by a scaling factor to compensate for the approximations so that they match the experimental outcome. Deriving scaling factors for harmonic frequencies has received a much of attention in the literature [10-14]. Derived scaling factors are specific to each level of theory used, but they also depend on the test set of molecules. In the literature usually global scaling factors are given for correcting the complete IR spectral range, although it is known that low and high frequencies are not equally affected by the deficiencies of the computational methods. When uniform scaling factors are used, large errors from the highly anharmonic low frequency modes enter in the scaling factors. Studies show the scaling factors for high and low frequencies can be very different which justifies the use of dual scaling [11]. There are published carbonyl frequency scaling factors for Fe-Fe complexes [15], or for diverse transition metal homoleptic carbonyls [16]. Nevertheless, the systematic errors arising from the basis sets of different transition metals are different. To the best of our knowledge, there is no systematic study for reliable and un-biased scaling of heteroleptic Rh-carbonyl complexes. 
Here we derive vibrational scaling factors for two commonly used DFT functionals from a large number of experimentally characterized $\mathrm{Rh}(\mathrm{I})$ carbonyl complexes. The newly derived vibrational scaling factors can help to assign the structure of spectroscopically observed intermediates in complex reaction networks. A reliable assignment of complex in situ or operando vibrational spectra stemming from $\mathrm{Rh}$-catalysed processes becomes possible.

\section{COMPUTATIONAL DETAILS}

A training set of 45 experimentally characterized $\mathrm{Rh}(\mathrm{I})$ carbonyl complexes was designed from chemical literature. All structures were optimized at the DFT level using two commonly used functionals: one generalized gradient approximation (GGA) functional (BP86 [17, 18]) and one hybrid functional (B3LYP [17, 19]). For all atomic orbitals, the def2-TZVP basis set was used [20] substituting previous Ahlrichs' basis sets [21]. This basis set was shown to give reliable vibrational $\mathrm{CO}$ frequencies for a number of metal complexes, see for example [22-24]. All final structures were characterized to be minima by calculating the Hessian matrices at the respective level and the absence of any imaginary eigenvalues. The frequencies corresponding to $\mathrm{CO}$ stretching vibrations were then used for comparison with experiment and derivation of a vibrational scaling factor. All calculations were done using TURBOMOLE V6.6 [25].

\section{RESULTS AND DISCUSSION}

A set of 45 carbonyl containing rhodium(I) complexes with available experimental IR spectroscopic data was selected from literature. The criteria for the selection were the formal oxidation state of rhodium to be +1 and the presence of one or two terminal carbonyl ligands. Complexes with bridging $\mathrm{CO}$ or clusters with more than one $\mathrm{Rh}$ atom were not included in the selection. It is beyond the scope of this study to individually discuss the $\mathrm{CO}$ stretching frequencies of each compound which span a range of $170 \mathrm{~cm}^{-1}$ (see below).

Both BP86 and B3LYP are known to generally reproduce structural parameters such as bond lengths and bond angles of transition metal complexes very well [26]. We here give one representative example complex from the test set, $\mathrm{Rh}(\mathrm{acac})(\mathrm{CO})_{2}$, a precursor of the catalyst in hydroformylation (Figure 2). The calculated structural parameters are in excellent agreement with the experiment from X-ray structural analysis [27]. Both shown bond lengths (rhodium- $\mathrm{CO}$ and $\mathrm{C}-\mathrm{O}$ ) are better reproduced by BP86 (to within $0.01 \AA$ ), whereas B3LYP overestimates the $\mathrm{Rh}-\mathrm{C}$ bonds by $0.3 \AA$, and underestimates $\mathrm{C}=\mathrm{O}$ distances by 0.05 $\AA$. This in turn yields higher $\mathrm{C}=\mathrm{O}$ vibrational frequencies not only in this complex but observed in all B3LYP calculations.

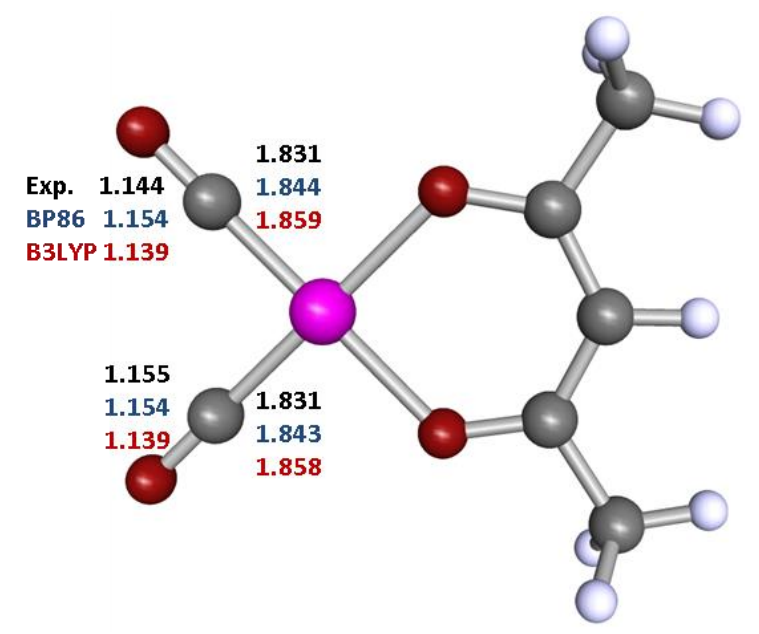

Figure 2. Comparison of experimentally obtained structure [27] of $\mathrm{Rh}(\mathrm{acac})(\mathrm{CO})_{2}$ to the calculated ones on BP86/def2-TZVP and B3LYP/def2-TZVP levels of theory. Values given in $\AA$.

These 45 complexes give a total of $69 \mathrm{CO}$ vibrational frequencies resulting from the presence of multiple carbonyl ligands in some of the complexes. The test set of 45 molecules along with their experimental and computed frequencies are given in Table 1. Although all of the 45 complexes are formal $\mathrm{Rh}(\mathrm{I})$ complexes, the carbonyl stretching frequencies are in a range from 1920 to $2095 \mathrm{~cm}^{-1}$ thus spanning more than $170 \mathrm{~cm}^{-1}$. This demonstrates that the $\mathrm{CO}$ stretching frequencies are subtle probes for the electron density at the central metal atom which is determined by the steric and electronic effects of the ligands. The 69 experimental frequencies are compared to the calculated ones with the BP86 and B3LYP DFT functionals. Although, it is known that the "exact" harmonic frequencies will always be greater than the true frequencies [28], our analysis shows that in the majority of cases BP86 underestimates CO experimental frequencies for the studied complexes. On the other hand, B3LYP being a hybrid functional including HF character, overshoots as expected in all of the cases. To precisely estimate the accuracy of the theoretical methods, the differences between the calculated unscaled and the experimental values are given in the $5^{\text {th }}$ and $7^{\text {th }}$ columns in Table 1 for 
BP86/def2-TZVP and B3LYP/def2-TZVP, respectively. We give the deviation from experiment as a signed percentage error. The maximal absolute error for BP86 is $2.9 \%$ and $6.5 \%$ is for B3LYP. The average absolute error is $1 \%$ for BP86 and 3.5\% for B3LYP.

Table 1. Set of molecules and the respective experimental and calculated $\mathrm{C}=\mathrm{O}$ frequencies used in this study. The error of the calculated frequencies with respect to the experimental given as signed percent.

\begin{tabular}{|c|c|c|c|c|c|c|}
\hline \multirow[t]{2}{*}{ Molecular formula } & \multirow[t]{2}{*}{$\begin{array}{c}\text { Structural } \\
\text { formula }\end{array}$} & \multicolumn{2}{|c|}{$v(\mathrm{CO})\left[\mathrm{cm}^{-1}\right]$} & \multicolumn{3}{|c|}{$\begin{array}{l}v(\mathrm{CO}) \\
{\left[\mathrm{cm}^{-1}\right]}\end{array}$} \\
\hline & & Exp. & BP86 & Error \% & B3LYP & Error \% \\
\hline 1 & 2 & 3 & 4 & 5 & 6 & 7 \\
\hline \multirow{2}{*}{$\mathrm{Rh}(\mathrm{CO})_{2} \mathrm{OOC}_{5} \mathrm{H}_{7}[29]$} & & 2084 & 2064.49 & -0.94 & 2145.6 & 2.96 \\
\hline & & 2015 & 2001.52 & -0.67 & 2084.8 & 3.46 \\
\hline \multirow{2}{*}{$\mathrm{RhC}_{14} \mathrm{H}_{14} \mathrm{NO}_{3}[30]$} & & 2068 & 2054.68 & -0.64 & 2136.51 & 3.31 \\
\hline & & 2000 & 1992.98 & -0.35 & 2075.39 & 3.77 \\
\hline \multirow{2}{*}{$\mathrm{RhC}_{10} \mathrm{H}_{14} \mathrm{NO}_{3}[30]$} & & 2070 & 2052.03 & -0.87 & 2134.71 & 3.13 \\
\hline & & 2003 & 1983.27 & -0.99 & 2064.68 & 3.08 \\
\hline \multirow{2}{*}{$\mathrm{RhC}_{13} \mathrm{H}_{12} \mathrm{NO}_{3}[30]$} & & 2065 & 2055.63 & -0.45 & 2137.52 & 3.51 \\
\hline & & 2005 & 1994.04 & -0.55 & 2076.59 & 3.57 \\
\hline $\mathrm{RhC}_{31} \mathrm{H}_{29} \mathrm{NO}_{2} \mathrm{P}[30]$ & & 1976 & 1982.55 & 0.33 & 2061.85 & 4.34 \\
\hline \multirow{2}{*}{$\begin{array}{c}\text { cis- } \mathrm{Rh}(\mathrm{CO})_{2}\left(\mathrm{PhNH}_{2}\right) \mathrm{Cl} \\
{[30]}\end{array}$} & & 2070 & 2038.87 & -1.50 & 2163.11 & 4.50 \\
\hline & & 2015 & 1969.44 & -2.26 & 2085.53 & 3.50 \\
\hline $\begin{array}{c}\mathrm{Rh}(\mathrm{CO})\left(\mathrm{S}\left(\mathrm{C}_{2} \mathrm{H}_{5}\right)_{2}\right)_{2} \mathrm{Cl} \\
{[31]}\end{array}$ & & 1965 & 1958.35 & -0.34 & 2034.45 & 3.53 \\
\hline $\begin{array}{c}\mathrm{Rh}(\mathrm{CO})\left(\mathrm{Se}\left(\mathrm{C}_{2} \mathrm{H}_{5}\right)_{2}\right)_{2} \mathrm{Cl} \\
{[31]}\end{array}$ & & 1961 & 1951.77 & -0.47 & 2028.31 & 3.43 \\
\hline $\begin{array}{c}\mathrm{Rh}(\mathrm{CO})\left(\mathrm{Te}\left(\mathrm{C}_{2} \mathrm{H}_{5}\right)_{2}\right)_{2} \mathrm{Cl} \\
{[31]}\end{array}$ & & 1955 & 1948.97 & -0.31 & 2021.33 & 3.39 \\
\hline \multirow{2}{*}{$\begin{array}{c}\mathrm{Rh}(\mathrm{CO})_{2}(2,6- \\
\left.\left(\mathrm{CH}_{3}\right)_{2} \mathrm{C}_{6} \mathrm{H}_{3} \mathrm{NH}_{2}\right) \mathrm{Cl}[30]\end{array}$} & & 2081 & 2067.71 & -0.64 & 2149.57 & 3.30 \\
\hline & & 2010 & 1995.42 & -0.73 & 2078.49 & 3.41 \\
\hline
\end{tabular}


Table 1. (Continuation)

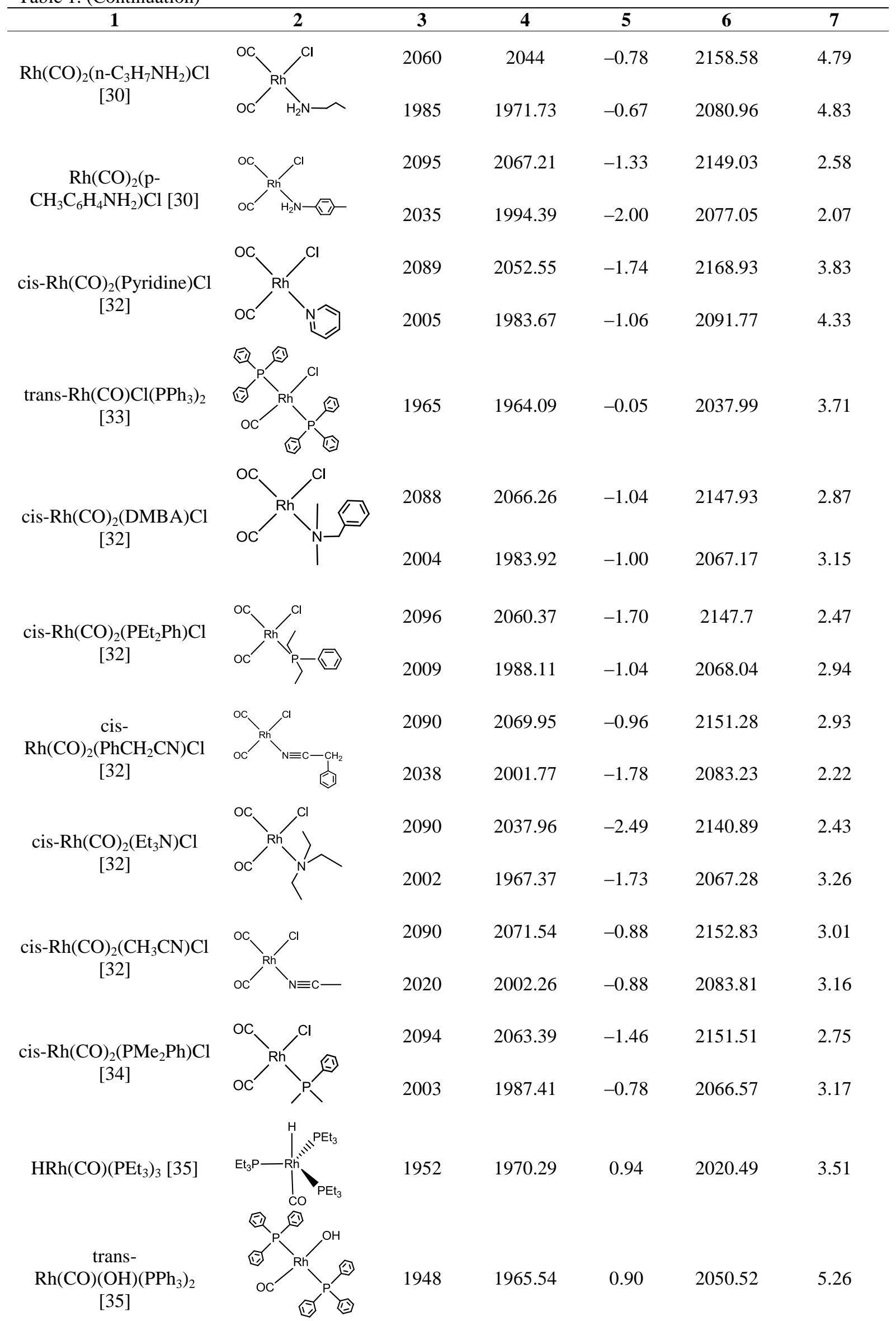


Table 1. (Continuation)

\begin{tabular}{|c|c|c|c|c|c|c|}
\hline 1 & 2 & 3 & 4 & 5 & 6 & 7 \\
\hline $\begin{array}{c}\mathrm{Rh}\left(\mathrm{C}_{2} \mathrm{~F}_{4} \mathrm{H}\right)(\mathrm{CO})\left(\mathrm{PPh}_{3}\right)_{2} \\
{[36]}\end{array}$ & & 1995 & 1975.14 & -1.00 & 2054.73 & 2.99 \\
\hline $\begin{array}{l}\mathrm{Rh}(\mathrm{Cl})(\mathrm{CO})(\mathrm{P}(\mathrm{p}- \\
\left.\left.\mathrm{CF}_{3} \mathrm{C}_{6} \mathrm{H}_{4}\right)_{3}\right)_{2}[37]\end{array}$ & & 1985 & 1974.2 & -0.54 & 2049.34 & 3.24 \\
\hline cis- $\mathrm{Rh}(\mathrm{CO})_{2}\left(\mathrm{PPh}_{2}\right) \mathrm{Cl}$ & & 2093 & 2061.82 & -1.49 & 2149.03 & 2.68 \\
\hline & & 2009 & 1987.26 & -1.08 & 2068.04 & 2.94 \\
\hline & & 2005 & 2015.03 & 0.50 & 2101.14 & 4.80 \\
\hline & & 1958 & 1963.6 & 0.29 & 2047.14 & 4.55 \\
\hline is $\mathrm{Db}(\mathrm{CO})(\mathrm{DD})$ & & 2092 & 2062.68 & -1.40 & 2150.73 & 2.81 \\
\hline & & 2008 & 1985.5 & -1.12 & 2064.73 & 2.83 \\
\hline & & 2084 & 2059.62 & -1.17 & 2138.03 & 2.59 \\
\hline & & 2007 & 1988.04 & -0.85 & 2070.21 & 3.25 \\
\hline $\begin{array}{c}\text { cis }-\mathrm{Rh}(\mathrm{Ph})(\mathrm{CO})\left(\mathrm{PPh}_{3}\right)_{2} \\
{[36]}\end{array}$ & & 1978 & 1954.64 & -1.18 & 2033.98 & 2.83 \\
\hline $\begin{array}{c}\text { cis- } \mathrm{Rh}(\mathrm{CO}) \mathrm{Cl}\left(\mathrm{PPH}_{3}\right)_{2} \\
{[38]}\end{array}$ & & 2010 & 2008.27 & -0.09 & 2089.84 & 3.97 \\
\hline $\mathrm{Rh}(\mathrm{CO})_{2}\left(\mathrm{PPh}_{3}\right)_{2}(\mathrm{Sn}$ & & 1975 & 1947.47 & -1.39 & 2026.93 & 2.63 \\
\hline $\begin{array}{c}\mathrm{HRhCO}\left(\mathrm{P}(\mathrm{n}-\mathrm{Butyl})_{3}\right)_{3} \\
{[35]}\end{array}$ & & 1960 & 1966.06 & 0.31 & 2016.4 & 2.88 \\
\hline $\begin{array}{c}\text { trans- } \\
\mathrm{Rh}(\mathrm{CO}) \mathrm{Cl}\left(\mathrm{PMe}_{2} \mathrm{Ph}\right)_{2} \\
{[34]}\end{array}$ & & 1964 & 1960.4 & -0.18 & 2092.26 & 6.53 \\
\hline
\end{tabular}


Table 1. (Continuation)

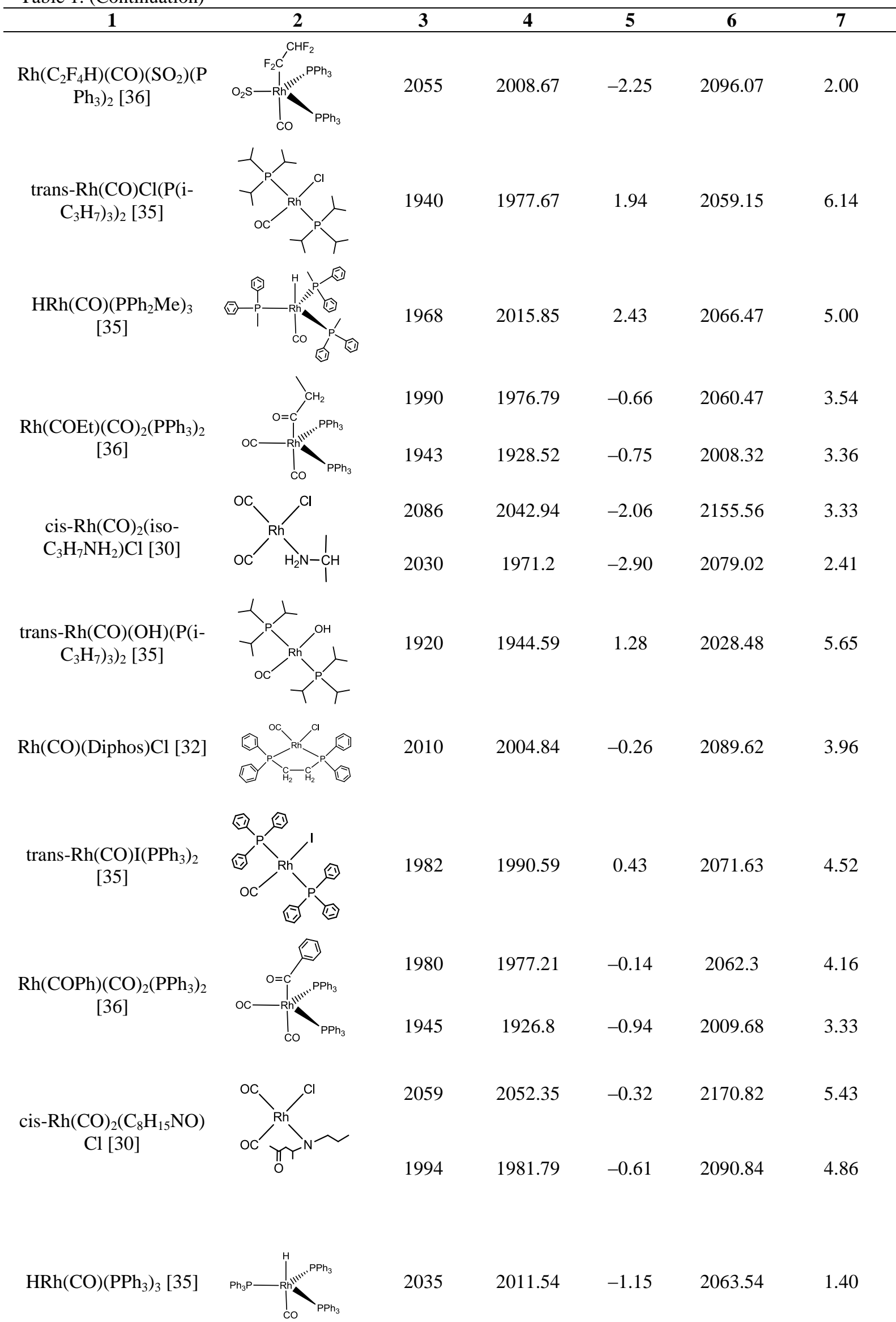


Table 1. (Continuation)

\begin{tabular}{ccccccc}
\hline $\mathbf{1}$ & $\mathbf{2}$ & $\mathbf{3}$ & $\mathbf{4}$ & $\mathbf{5}$ & $\mathbf{6}$ & $\mathbf{7}$ \\
\hline $\mathrm{HRh}(\mathrm{CO})\left(\mathrm{PPhEt}_{2}\right)_{3}[35]$ & & & & & & \\
& & & & & & \\
\hline
\end{tabular}

The correlation between the experimental set of data and the two calculated sets of data was estimated and the fitting to a linear function shows a slope close to $6 / 8$ for the BP86 values and a slope of $7 / 8$ for the B3LYP values (Figure 3). This confirms the slightly better linear correlation of B3LYP to experiment in comparison with BP86 which was also observed in other studies [40].

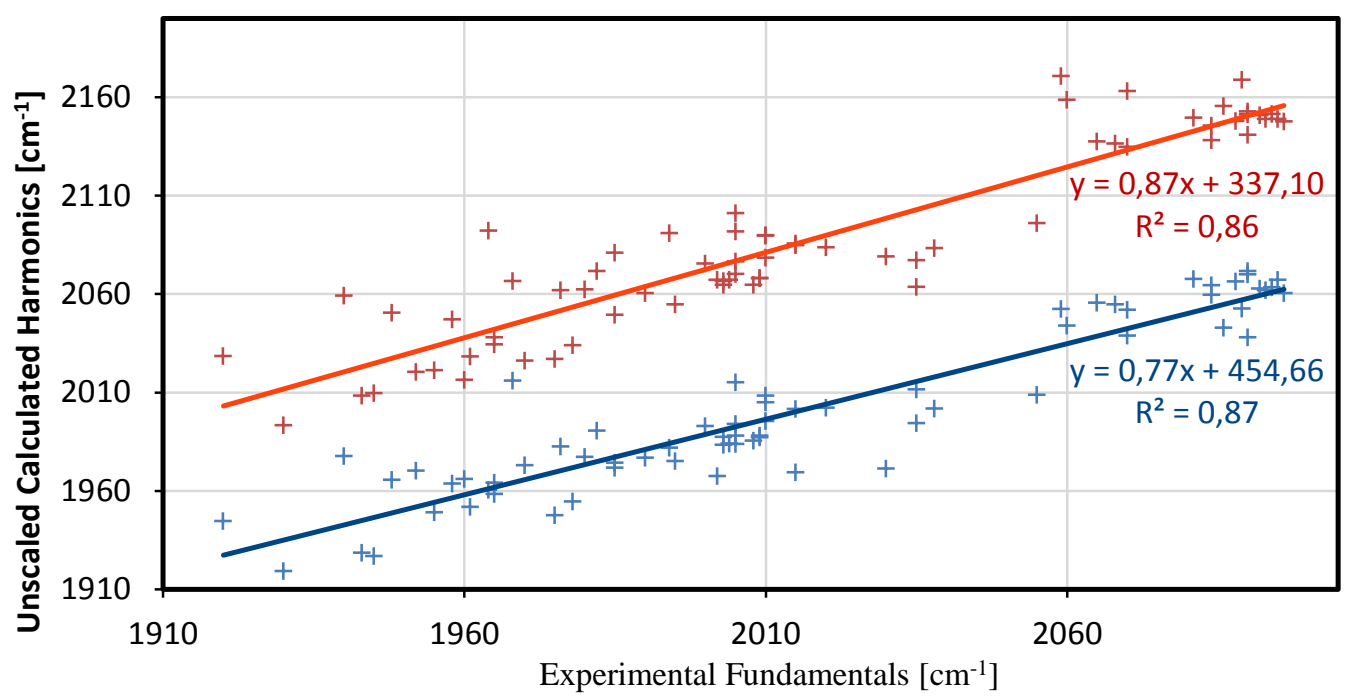

Figure 3. Comparison of experimental CO stretching frequencies for $45 \mathrm{Rh}(\mathrm{I})$ complexes and computed with BP86/def2-TZVP (blue) and B3LYP/def2-TZVP (red) ones.

Using the experimental and calculated values from Table 1, vibrational frequency scaling factors for the both of the DFT methods were determined by minimizing the sum of the square of the errors (Equation (1)):

$$
\Delta_{\mathrm{vib}}=\sum_{i}\left(\lambda(\mathrm{CO}) \omega_{i}(\mathrm{CO})-v_{i}(\mathrm{CO})\right)^{2},
$$

where $\omega_{i}(\mathrm{CO})$ is the $i$-th calculated $\mathrm{CO}$ harmonic stretching frequency on the respective level of theory, whereas $v_{i}(\mathrm{CO})$ is the corresponding experimental fundamental carbonyl stretching frequency. The frequencies are given in $\mathrm{cm}^{-1}$. The minimized residual for each analysed frequency was calculated as:

$$
\Delta_{\min }=\left(\lambda(\mathrm{CO}) \omega_{i}(\mathrm{CO})-v_{i}(\mathrm{CO})\right)^{2}
$$

$\lambda(\mathrm{CO})$ is the scaling factor for carbonyl frequencies given by:

$$
\lambda(\mathrm{CO})=\frac{\sum_{i} \omega_{i}(\mathrm{CO}) v_{i}(\mathrm{CO})}{\sum_{i}\left(\omega_{i}(\mathrm{CO})\right)^{2}}
$$

Vibrational scaling factors of 1.0074 and 0.9662 were obtained for BP86/def2-TZVP and B3LYP/def2-TZVP, respectively. The results are summarized in Table 2.

Table 2. Frequency scaling factors derived for CO stretching vibrations and corresponding RMSE values

\begin{tabular}{lccc}
\hline Method & Scale factor & RMSE before scaling $/ \mathrm{cm}^{-1}$ & RMSE after scaling $/ \mathrm{cm}^{-1}$ \\
\hline BP86/def2-TZVP & 1.0074 & 24.03 & 18.85 \\
B3LYP/def2-TZVP & 0.9662 & 72.99 & 18.80 \\
\hline
\end{tabular}


The root mean squared error (RMSE) for both of the methods is calculated as a single measure of accuracy according to Equation (4). The values for the RMSE before and after scaling are presented along with the scaling factors in Table 2.

$$
\operatorname{RMSE}=\left(\sum_{1}^{n} \Delta_{\min } / n_{\mathrm{all}}\right)^{1 / 2}
$$

where $n$ is the number of all analysed frequencies.

Before scaling, BP86 shows RMSE of $24 \mathrm{~cm}^{-1}$ which is three times smaller than the RMSE for B3LYP $\left(73 \mathrm{~cm}^{-1}\right)$. After the scaling, a RMSE of $18.8 \mathrm{~cm}^{-1}$ was obtained for both methods.

Our scaling factors are in line with those from Assefa et al. of 1.012 and 0.968 for BP86/def2-TZVP and B3LYP/def2-TZVP, respectively. These scaling factors were derived for different transition metal homoleptic carbonyl complexes but not for Rh complexes [16].

To better illustrate the effect of the scaling, the distribution of the deviations from experiment before and after scaling is shown in Figure 4. It can be seen that the unscaled B3LYP values are significantly dispersed around the experimental values (more than one third of the B3LYP errors are larger than $70 \mathrm{~cm}^{-1}$ ) and using unscaled B3LYP frequencies can lead to possible difficulties in the interpretation or to misinterpretation of the experimental spectra. On the other hand, BP86 frequencies can even be used without scaling considering that they only might be slightly lower than the experimental ones. After scaling, both methods are equally good in reproducing the experimental $\mathrm{CO}$ frequencies.

Kershawani et al. were the first to derive a vibrational scaling factor for the Weigend-Ahlrichs basis sets for a benchmark set of small organic molecules [41]. Amongst others, they investigated the convergence of accuracy of calculated vibrational frequencies with basis set size. They obtained a RMSE for the BP86 exchange-correlation functional after scaling using SVP $\left(38 \mathrm{~cm}^{-1}\right)$, def2TZVP $\left(26 \mathrm{~cm}^{-1}\right)$, def2-TZVPD $\left(25 \mathrm{~cm}^{-1}\right)$, def2TZVPP $\left(24 \mathrm{~cm}^{-1}\right)$ to an extrapolated basis set limit CBSB7 $\left(30 \mathrm{~cm}^{-1}\right)$. For B3LYP, the RMSEs were SVP $\left(39 \mathrm{~cm}^{-1}\right)$, def2-TZVP $\left(27 \mathrm{~cm}^{-1}\right)$, def2-TZVPD $\left(27 \mathrm{~cm}^{-1}\right)$, def2-TZVPP $\left(26 \mathrm{~cm}^{-1}\right)$ and CBSB7 (30 $\left.\mathrm{cm}^{-1}\right)$. This demonstrates the appropriateness of the def2-TZVP basis set for calculation vibrational frequencies. A larger basis set does not necessarily improve the accuracy of calculated frequencies.

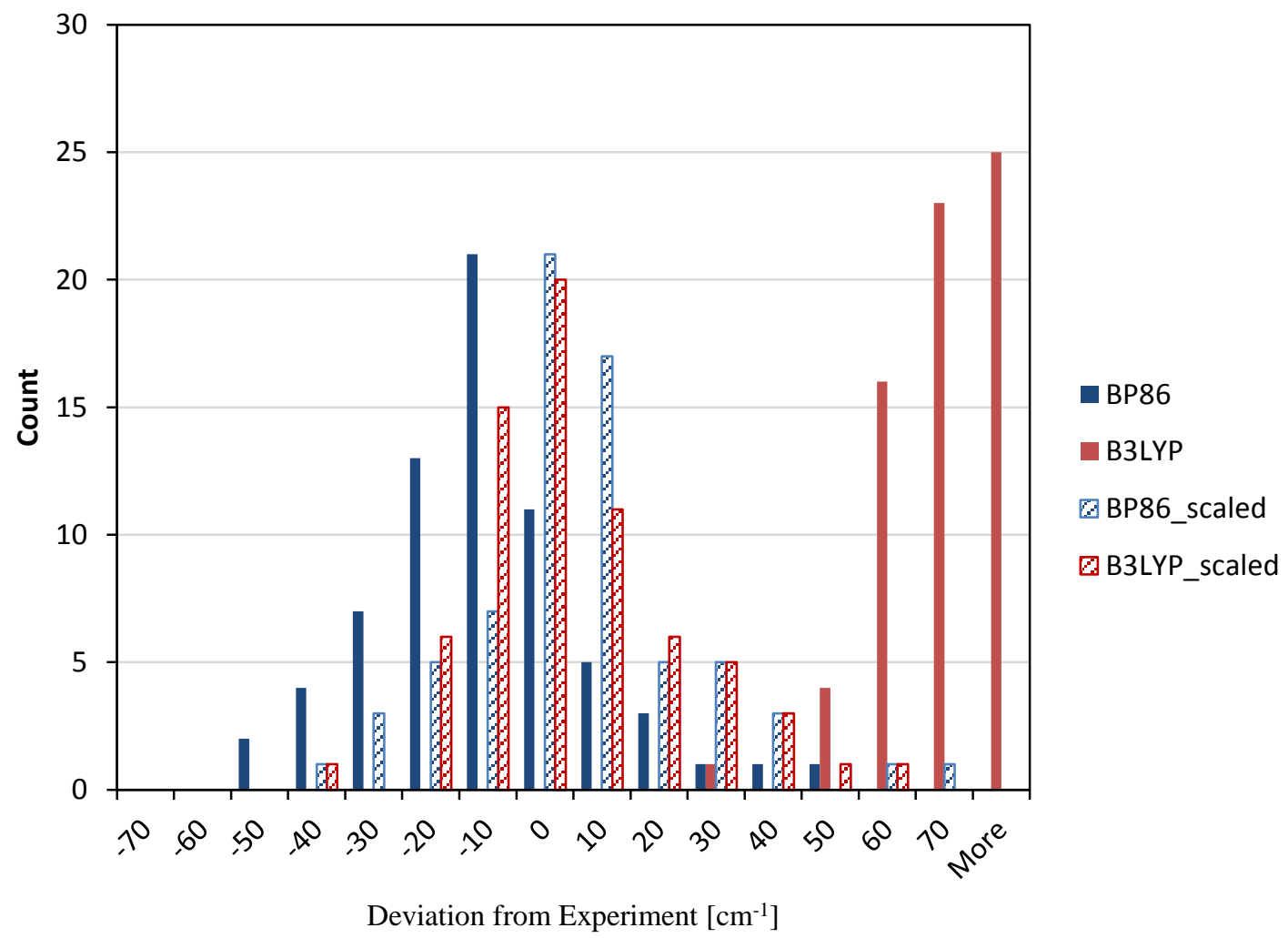

Figure 4. Histogram of $\mathrm{CO}$ stretching frequency differences between computed harmonics and observed fundamentals for unscaled and scaled BP86/def2-TZVP (blue) and B3LYP/def2-TZVP (red) level of theory. 
One of the major concerns with quantum chemically calculated vibrational frequencies is the use of the rigid rotor harmonic oscillator (RRHO) approximation. For small molecules, the calculation of accurate anharmonic force fields is a practical option, see for example [42], but this becomes not feasible for larger molecules. For $\mathrm{Ni}(\mathrm{CO})_{4}$, for example, the estimated anharmonicity constants from isotope experiments are between -3 and $-11 \mathrm{~cm}^{-1}$ [43] and would bring calculated frequencies in even closer agreement with experiments. The use of a simple vibrational scaling factor aims to correct for (i) inherent deficiencies of the electronic structure methods, and (ii) the potential energy surface to be not harmonic.

In order to illustrate the usefulness of vibrational scaling factors on practical examples, we have chosen two $\mathrm{Rh}(\mathrm{I})$ catalyst complexes to assign experimental IR spectra.

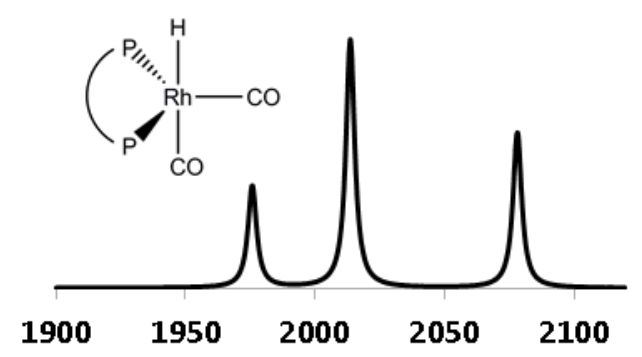

$\mathrm{HRh}(\mathrm{BiPhePhos})(\mathrm{CO})_{2}$ is a saturated 18electron species with a trigonal bipyramidal structure and is supposed to give rise to a 3 bands pattern in the carbonyl stretching region. $\mathrm{HRh}(\mathrm{BiPhePhos})(\mathrm{CO})_{2}$ is the "resting state" or "pre-catalyst" prior to hydroformlylation of long chain olefins. The "resting state" is activated by dissociation of one of the CO ligands. The bidentate phosphite ligand can coordinate around the $\mathrm{Rh}$ central atom in two different ways: the two phosphorous atoms may occupy two equatorial $(e, e)$ positions or one equatorial and one axial $(\mathrm{e}, \mathrm{a})$. The equatorial-equatorial positioning can be discriminated from the equatorial-axial one according to the pattern in the carbonyl region originating from the two carbonyl groups and the hydride in the complex as shown in Figure 5. The comparison of both calculated spectra to the experimental one (compare Figures 5 and 6) led to successful assignment of the structure to the e,e configuration.

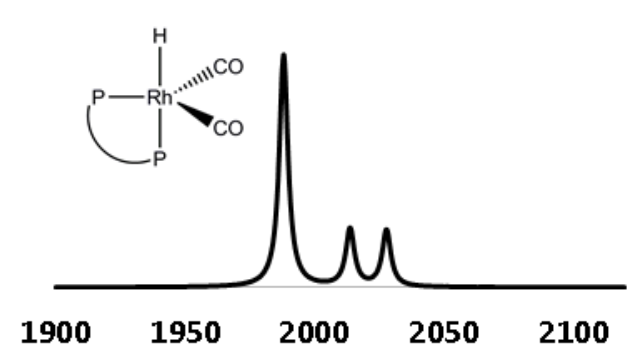

Figure 5. Two isomeric forms of a hydrido-dicarbonyl complex containing a bidentate ligand $\left(\mathrm{HRh}(\mathrm{BPP})(\mathrm{CO})_{2}\right)$ and their respective calculated IR spectra. Left: equatorial-equatorial (e,e) positioning. Right: equatorial-axial (e,a) positioning. Values are given in $\mathrm{cm}^{-1}$.
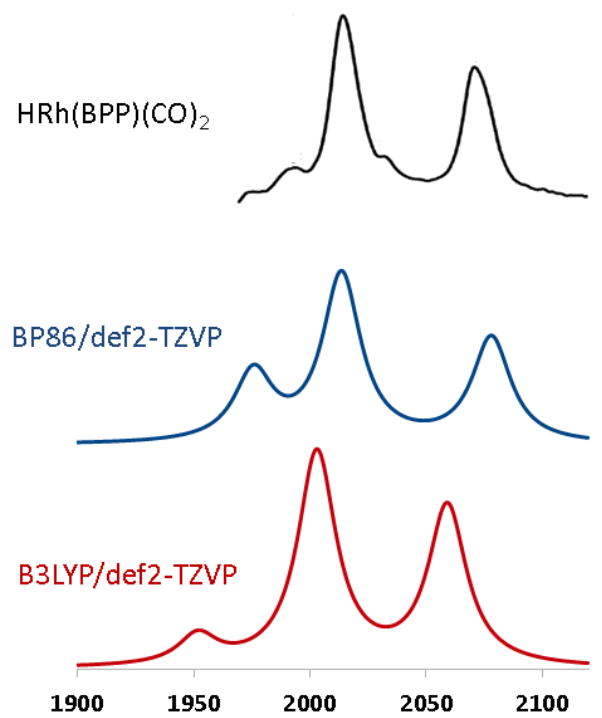

Figure 6. Comparison of the experimental spectrum of $\mathrm{HRh}(\mathrm{BPP})(\mathrm{CO})_{2} \mathrm{e}$,e and the spectra predicted by two DFT functionals using the vibrational scaling factors derived in this study. Values are given in $\mathrm{cm}^{-1}$.
Figure 6 shows the experimental spectrum of this complex compared to the DFT calculated spectra for the e,e isomer. The weak absorption at 1993 $\mathrm{cm}^{-1}$ and the shoulder at $2033 \mathrm{~cm}^{-1}$ were assigned to a small moiety of the e,a isomer present in the mixture in the original work [44]. The weak absorption below $2000 \mathrm{~cm}^{-1}$ is commonly identified as $\mathrm{Rh}-\mathrm{H}$ stretch. Nevertheless, such a band was not assigned in the original study. By means of first principles, we can thus reliably assign the vibrational peak. All three bands seen in the calculated spectra originate from coupling of the two $\mathrm{Rh}-\mathrm{CO}$ and one $\mathrm{Rh}-\mathrm{H}$ vibrational modes.

The calculated spectra are in good agreement with the experimental spectrum for both of the functionals in terms of peak positioning and, additionally, correctly reproduce the relative absorption intensities with the lower frequency band to be more intense. The exact position of the bands and the deviations from experiment are summarized in Table 3. The absolute deviation of $0.6 \%$ (taken as 
arithmetic mean for both of the bands) for the unscaled values reduces to $0.2 \%$ for BP86 and the deviation of $2.8 \%$ for B3LYP reduces to $0.6 \%$.

Scaling $\mathrm{CO}$ stretches by uniform scaling parameters (applicable to the entire IR range) can lead to even larger deviations instead of correcting them. In this example, applying the global scaling factors of 1.0337 and 1.0044 for BP86/def2-TZVP and B3LYP/def2-TZVP respectively, derived by Kesharwani et al. [12] will blueshift both BP86 and B3LYP frequencies (Table 3). For BP86 it will be too high blueshifted than necessary (increase of the absolute deviation from 0.6 to $2.8 \%$ ) and for B3LYP no blueshifting is needed in the first place, but redshifting (increase of the absolute error from 2.8 to $3.3 \%$ ). This can be misleading for organometallic chemists who rely on the carbonyl spectral range in identifying carbonyl containing intermediates.

We bring a further example, $\mathrm{HRh}(\mathrm{SX})(\mathrm{CO})_{2}$. The electron richer SulfoXantPhos (SX) ligand has the effect of weakening the $\mathrm{C}=\mathrm{O}$ bond and redshifting its frequencies in comparison to its analogue BiPhePhos. The experimental [45] and the calculated frequencies for the e,e isomer of $\mathrm{HRh}(\mathrm{SX})(\mathrm{CO})_{2}$ are given in Table 3. The higher vibration at 2032 $\mathrm{cm}^{-1}$ is one of the rare examples where BP86 yields a higher value than the experimental. Thus, scaling this frequency increases the deviation from experiment. This vibration originates from a coupled stretching motion of the axial hydride and axial carbonyl ligand. Given that the experiment was performed at a high pressure of $\mathrm{CO}$ and $\mathrm{H}_{2}$ (HPIR), we suggest that this vibration is most sensitive to increase in pressure. At high pressure, the $\mathrm{Rh}-\mathrm{H}$ bond decreases in distance, the metal becomes more electron rich and this leads to a lower than expected $\mathrm{C}=\mathrm{O}$ vibration. Nevertheless, the low frequency after scaling deviates only $1 \mathrm{~cm}^{-1}$ from the experimental value.

Table 3. Experimental and calculated $\mathrm{CO}$ frequencies and their absolute deviations for $\mathrm{HRh}(\mathrm{BPP})(\mathrm{CO})_{2}$ and $\mathrm{HRh}(\mathrm{SX})(\mathrm{CO})_{2} .3^{\text {rd }}$ and $6^{\text {th }}$ column - raw calculated frequencies; $4^{\text {th }}$ and $7^{\text {th }}$ column - scaled by the scale factors (sf) derived in this study; $5^{\text {th }}$ and $8^{\text {th }}$ column - scaled by a uniform scale factors.

\begin{tabular}{|c|c|c|c|c|c|c|c|}
\hline & Exp & BP86 & $\begin{array}{l}\text { BP86 } \\
\text { scaled }\end{array}$ & $\begin{array}{c}\text { BP86 } \\
\text { scaled by } \\
\text { uniform sf } \\
{[12]}\end{array}$ & B3LYP & $\begin{array}{l}\text { B3LYP } \\
\text { scaled }\end{array}$ & $\begin{array}{c}\text { B3LYP } \\
\text { scaled by } \\
\text { uniform sf } \\
{[12]}\end{array}$ \\
\hline $\mathrm{HRh}(\mathrm{BPP})(\mathrm{CO})_{2}$ & [37] & & & & & & \\
\hline \multirow[t]{2}{*}{$v(\mathrm{CO})\left[\mathrm{cm}^{-1}\right]$} & 2071 & 2063 & 2078 & 2133 & 2129 & 2057 & 2138 \\
\hline & 2015 & 1999 & 2013 & 2066 & 2073 & 2003 & 2082 \\
\hline \multirow[t]{2}{*}{$\Delta v(\mathrm{CO})\left[\mathrm{cm}^{-1}\right]$} & & 8 & 7 & 62 & 58 & 14 & 67 \\
\hline & & 16 & 2 & 51 & 58 & 12 & 67 \\
\hline$\left[\mathrm{HRh}(\mathrm{SX})(\mathrm{CO})_{2}\right]^{2-}$ & [38] & & & & & & \\
\hline \multirow[t]{2}{*}{$v(\mathrm{CO})\left[\mathrm{cm}^{-1}\right]$} & 2032 & 2041 & 2056 & 2109 & 2102 & 2031 & 2111 \\
\hline & 1967 & 1951 & 1966 & 2017 & 2011 & 1943 & 2020 \\
\hline \multirow[t]{2}{*}{$\Delta v(\mathrm{CO})\left[\mathrm{cm}^{-1}\right]$} & & 9 & 24 & 77 & 70 & 1 & 79 \\
\hline & & 16 & 1 & 50 & 44 & 24 & 53 \\
\hline
\end{tabular}

\section{CONCLUSIONS}

We derived vibrational scaling factors from a data set of $45 \mathrm{Rh}$ (I) carbonyl complexes. Two representative DFT functionals (BP86 and B3LYP) were used. For reliable interpretation of experimental IR spectra, scaling of the frequencies by the here presented scale parameters for both of the methods is necessary. Global scaling factors found in literature are not recommended to be used for $\mathrm{CO}$ stretches in transition metal carbonyl complexes. If necessary, at least scaling factors for high frequencies should be employed. Comparing the computational times of both of the methods, BP86 is shown to be much more attractive requiring much less computational time and providing better accuracy without and same accuracy after scaling. As shown before [16] the scaling factors vary insignificantly with the basis set, which makes our derived scale factors also applicable to other basis sets.

Acknowledgements. We thank the Max Planck Society for the Advancement of Science for financial support. This work is part of the Collaborative Research Center / Transregio 63 "Integrated Chemical Processes in Liquid Multiphase Systems" (subproject A4) supported by Deutsche Forschungsgemeinschaft (DFG, German Research Foundation). We also thank Khaled Elbassyouni for performing the structural optimizations. 


\section{REFERENCES}

[1] R. Franke, D. Selent, A. Börner, Applied hydroformylation, Chemical reviews, 112 (11) (2012), pp. 5675-5732.

[2] P. W. Van Leeuwen, C. Claver, Rhodium Catalyzed Hydroformylation, Springer Science \& Business Media, 22, 2002.

[3] B. Moasser, W. L. Gladfelter, D. C. Roe, Mechanistic aspects of a highly regioselective catalytic alkene hydroformylation using a rhodium chelating bis (phosphite) complex. Organometallics, 14 (1995), pp. 3832-3838.

[4] D. Selent et al., A new diphosphite promoting highly regioselective rhodium-catalyzed hydroformylation, Organometallics, 30 (2011), pp. 4509-4514.

[5] J. H. Jones, The cativa ${ }^{\mathrm{TM}}$ process for the manufacture of acetic acid, Platinum Metals Review, 44 (2000), pp. 94-105.

[6] O. Diebolt, P. W. van Leeuwen, P. C. Kamer, Operando spectroscopy in catalytic carbonylation reactions, Acs Catalysis, 2 (2012) pp. 2357-2370.

[7] C. Sosa et al., A local density functional study of the structure and vibrational frequencies of molecular transition-metal compounds, J. Phys. Chem., 96 (1992), pp. 6630-6636.

[8] A Bérces, T. Ziegler, Application of density functional theory to the calculation of force fields and vibrational frequencies of transition metal complexes, in Density Functional Theory III. Springer. 1996, pp. 41-85.

[9] W. J. Hehre, Ab Initio Molecular Orbital Theory, Wiley-Interscience, 1986.

[10] G. Rauhut, P. Pulay, Transferable scaling factors for density functional derived vibrational force fields, J. Phys. Chem., 99 (1995), pp. 3093-3100.

[11] M. D. Halls, J. Velkovski, H. B. Schlegel, Harmonic frequency scaling factors for HartreeFock, S-VWN, B-LYP, B3-LYP, B3-PW91 and MP2 with the Sadlej pVTZ electric property basis set, Theor. Chem. Acc., 105 (6) (2001), pp. 413421.

[12] M. K. Kesharwani, B. Brauer, J. M. Martin, Frequency and zero-point vibrational energy scale factors for double-hybrid density functionals (and other selected methods): can anharmonic force fields be avoided?, J. Phys. Chem. A, 119 (2014), pp. 1701-1714.

[13] P. Sinha et al., Harmonic vibrational frequencies: scaling factors for HF, B3LYP, and MP2 methods in combination with correlation consistent basis sets, J. Phys. Chem. A, 108 (2004), pp. 9213-9217.

[14] A. P. Scott, L. Radom, Harmonic vibrational frequencies: an evaluation of Hartree- Fock, Møller- Plesset, quadratic configuration inter- action, density functional theory, and semiempirical scale factors, J. Phys. Chem., 100 (1996), pp. 16502-16513.

[15] J. W. Tye, M. Y. Darensbourg, M. B. Hall, Correlation between computed gas-phase and experimentally determined solution-phase infrared spectra: Models of the iron-iron hydrogenase enzyme active site, J. Comp. Chem., 27 (2006), pp. 1454-1462.

[16] M. Assefa et al., Vibrational scaling factors for transition metal carbonyls, Chem. Phys. Lett., 640 (2015), pp. 175-179.

[17] A. D. Becke, Density-functional exchange-energy approximation with correct asymptotic behavior, Phys. Rev. A, 38 (1988), pp. 3098-3100.

[18] J. P. Perdew, Density-functional approximation for the correlation energy of the inhomogeneous electron gas, Phys. Rev. B, 33 (1986), p. 8822.

[19] C. Lee, W. Yang, R. G. Parr, Development of the Colle-Salvetti correlation-energy formula into a functional of the electron density, Phys. Rev. B, 37 (1988), p. 785.

[20] F. Weigend, R. Ahlrichs, Balanced basis sets of split valence, triple zeta valence and quadruple zeta valence quality for $\mathrm{H}$ to $\mathrm{Rn}$ : Design and assessment of accuracy, Phys. Chem. Chem. Physics, 7 (2005), pp. 3297-3305.

[21] A. Schäfer, C. Huber, R. Ahlrichs, Fully optimized contracted Gaussian basis sets of triple zeta valence quality for atoms Li to K, J. Chem. Phys., 100 (1994), pp. 5829-5835.

[22] A. R. Finkelmann, M. T. Stiebritz, M. Reiher, Inaccessibility of the [small mu ]-hydride species in [FeFe] hydrogenases, Chem. Sci., 5 (1) (2014) pp. 215-221.

[23] P. Henke et al., Snapshots of the Al-Al $\sigma$-Bond Formation Starting from $\{$ AlR2 $\}$ Units: Experimental and Computational Observations, Angewandte Chemie International Edition, 48 (2009), pp. 8141-8145.

[24] J. Kreutzer, P. Blaha, U. Schubert, Assessment of different basis sets and DFT functionals for the calculation of structural parameters, vibrational modes and ligand binding energies of $\mathrm{Zr}_{4} \mathrm{O}_{2}$ (carboxylate)12 clusters, Comp. Theor. Chem., 1084 (2016), pp. 162-168.

[25] TURBOMOLE V6.6 2014, A development of University of Karlsruhe and Forschungszentrum Karlsruhe GmbH, 1989-2007, TURBOMOLE $\mathrm{GmbH}$, since 2007; available from http://www. turbomole.com.

[26] A. C. Tsipis, DFT flavor of coordination chemistry, Coordination Chemistry Reviews, 272 (2014), pp. 1-29.

[27] F. Huq, A. C. Skapski, Refinement of the crystal structure of acetylacetonatodicarbonylrhodium (I), J. Crys. Mol. Str., 4 (1974), pp. 411-418. 
[28] C. J. Cramer, Essentials of Computational Chemistry: Theories and Models. John Wiley \& Sons, 2013.

[29] V. Cervetto et al., Double-resonance versus pulsed Fourier transform two-dimensional infrared spectroscopy: An experimental and theoretical comparison, J. Chem. Phys., 121 (2004), pp. 5935-5942.

[30] F. Bonati, R. Ugo, Rhodium (I) and iridium (I) carbonyl derivatives of some Schiff bases of acetylacetone, J. Organomet. Chem., 7 (1967) pp. $167-180$.

[31] F. Faraone, R. Pietropaolo, S. Sergi, Ligand effects on oxidative addition reactions of $\mathrm{d} 8$ metal complexes, J. Organomet. Chem., 24 (1970), pp. 797-803.

[32] L. Rollmann, Bridge-splitting reactions of rhodium carbonyl chloride with monomeric and polymeric ligands, Inorg. Chim. Acta, 6 (1972), pp. 137-140.

[33] K. Joseph et al., Five-coordinated rhodium (I) carbonyl compounds, Inorg. Chim. Acta, $\mathbf{8 4}$ (1984), pp. 149-151.

[34] A. Janssen, J. Niederer, W. Hölderich, Investigation of rhodium complexes in micro- and mesoporous materials by computer modeling, FTIR, and 31P MAS NMR, Catal. Lett., 48 (1997), pp. 165-171.

[35] G. Gregorio, G. Pregaglia, R. Ugo, Hydrogen transfer reaction from alcohols catalysed by rhodium carbonyl phosphine complexes, Inorg. Chim. Acta, 3 (1969), pp. 89-93.

[36] G. Yagupsky, C. Brown, G. Wilkinson, Further studies on hydridocarbonyltris (triphenylphosphine) rhodium (I); intermediate species in hydroformylation; rhodium and iridium analogues, J. Chem. Soc. A: Inorg., Phys., Theor., 1970, pp. 1392-1401.

[37] D. R. Palo, C. Erkey, Homogeneous catalytic hydroformylation of 1-octene in supercritical carbon dioxide using a novel rhodium catalyst with fluorinated arylphosphine ligands, Industrial
\& Engineering Chemistry Research, 37, (1998), pp. 4203-4206.

[38] P. Das et al., Synthesis of a rhodium (I) carbonyl complex with a chiral aminodiphosphine ligand and its immobilization onto aminopropyl functionalized silica gel, J. Coord. Chem., 63 (2010), pp. 1107-1117.

[39] J. P. Collman, F. D. Vastine, W. R. Roper, Pentacoordinate iridium (I) and rhodium (I) complexes derived from metal carbonyl anions, J. Am. Chem. Soc., 90 (1968), pp. 2282-2287.

[40] X. Rozanska et al., High-throughput calculations of molecular properties in the MedeA environment: Accuracy of PM7 in predicting vibrational frequencies, ideal gas entropies, heat capacities, and Gibbs free energies of organic molecules, J. Chem. Eng. Data, 59 (2014), pp. 3136-3143.

[41] M. K. Kesharwani, B. Brauer, J. M. L. Martin, Frequency and zero-point vibrational energy scale factors for double-hybrid density functionals (and other selected methods): Can anharmonic force fields be avoided?, J. Phys. Chem. A, 119 (2015), pp. 1701-1714.

[42] A. Karton, E. Rabinovich, J. M. L. Martin, W4 theory for computational thermochemistry: In pursuit of confident sub-kJ/mol predictions, $J$. Chem. Phys., 125 (2006), p. 144108.

[43] L. H. Jones, R. S. McDowell, M. Goldblatt, Force constants of nickel carbonyl from vibrational spectra of isotopic species, J. Chem. Phys., 48 (1968), p. 2663-+.

[44] C. Kubis, Untersuchungen zur Kinetik der Hydroformylierung mit Phosphit-modifizierten Rhodiumkatalysatoren unter Einsatz der in situ IRSpektroskopie, 2012, (Doktoral dissertation).

[45] P. Raymond, P. W. van Leeuwen, High pressure infrared and nuclear magnetic resonance studies of the rhodium-sulfoxantphos catalysed hydroformylation of 1-octene in ionic liquids, New Jour. Chem., 27 (2003), pp. 1294-1296.

\title{
ВИБРАЦИОНИ СКАЛИРАЧКИ ФАКТОРИ ЗА Rh(I) КАРБОНИЛНИ СОЕДИНЕНИЈА ВО ХОМОГЕНАТА КАТАЛИЗА
}

\author{
Emilija Kohls", Matthias Stein \\ Max Planck Institute for Dynamics of Complex Technical Systems, \\ Molecular Simulations and Design Group, Magdeburg, Germany
}

Метал карбонилните комплекси се важно семејство на катализатори во хомогените индустриски процеси. Нивните карактеристични вибрациони фреквенции овозможуваат in situ следење на каталитичкиот прогрес. Структурното асигнирање на интермедиери е често отежнато поради недостиг на референти соединенија. Пресметките $A b$ inicio на карбонилните вибрациони фреквенции нудат алтернативна алатка за 
идентификација на реактивни интермедиери. Скалирачки фактори за компјутерски пресметани карбонилни валентни фреквенции беа изведени од сет од 45 карбонилни комплекси на родиум користејќи ги функционалите BP86 и B3LYP. Систематичното скалирање на пресметаните $\mathrm{C}=\mathrm{O}$ фреквенции овозможи веродостојно предвидување и асигнирање на експерименталните вредности на $v(\mathrm{CO})$. Овие вибрациони скалирачки фактори можат да послужат за идентификација на реакциони интермедиери во индустриски релевантната реакција на хидроформилација катализирана со родиумови комплекси. Апсолутната девијација помеѓу пресметаните и експерименталните спектри беше значително намалена и експериментални спектри беа успешно асигнирани.

Клучни зборови: инфрацрвена спектроскопија; вибрациони скалирачки фактори; карбонилни комплекси на родиум; хидроформилација; теорија на функционал од густина (ДФТ) 